\title{
Revision of sea anemone genus Epiactis (Coelenterata: Actiniaria) on the Pacific coast of North America, with descriptions of two new brooding species
}

\author{
Daphne Gail Fautin \\ Department of Invertebrate Zoology, California Academy of Sciences, Golden Gate Park, \\ San Francisco, CA, U.S.A. 94118-9961 \\ AND \\ FU-SHIANG CHIA \\ Department of Zoology, University of Alberta, Edmonton, Alta., Canada T6G $2 E 9$ \\ Received August 21, 1985
}

\begin{abstract}
FAUtin, D. G., and F.-S. ChiA. 1986. Revision of sea anemone genus Epiactis (Coelenterata: Actiniaria) on the Pacific coast of North America, with descriptions of two new brooding species. Can. J. Zool. 64: 1665-1674.

Two new species of the actiniid genus Epiactis, Epiactis lisbethae and Epiactis fernaldi, are described from the intertidal zone of the San Juan Islands, Washington, U.S.A. The sea anemone genus Cnidopus is synonymized with Epiactis, and its type species, $C$. ritteri, is restored to the genus in which it was originally described. Thus, four species of Epiactis are known on the Pacific coast of North America: external brooders $E$. prolifera (type species of the genus) and $E$. lisbethae, which differ in sexuality and brooding periodicity; and internal brooders $E$. ritteri and $E$. fernaldi, which differ in cnidae, sexuality, and histology. These bring the number of nominal species in the genus Epiactis to 19.
\end{abstract}

Fautin, D. G., et F.-S. ChiA. 1986. Revision of sea anemone genus Epiactis (Coelenterata: Actiniaria) on the Pacific coast of North America, with descriptions of two new brooding species. Can. J. Zool. 64: 1665-1674.

On trouvera ici la description de deux nouvelles espèces d'Actiniidae du genre Epiactis, Epiactis lisbethae et Epiactis fernaldi, de la zone intercotidale des Îles San Juan, Washington, États-Unis. Le genre d'anémone de mer Cnipodus devient synonyme d'Epiactis et l'espèce-type, $C$. ritteri, est reclassifiée dans le genre sous le nom duquel elle avait d'abord été décrite. Il y a donc quatre espèces d'Epiactis le long de la côte du Pacifique en Amérique du Nord: E. prolifera (espèce type du genre), et $E$. lisbethae qui portent leur progéniture à l'extérieur, mais qui diffèrent par leur sexualité et la périodicité de leur reproduction, et deux espèces qui portent leur progéniture à l'intérieur, $E$. ritteri et $E$. fernaldi, qui diffèrent par leurs cnidoblastes, par leur sexualité et par leur histologie. L'addition de ces deux espèces porte à 19 le nombre d'espèces nominales du genre Epiactis.

[Traduit par la revue]

\section{Introduction}

The sea anemone Epiactis prolifera was described by Verrill (1869) from specimens collected in Puget Sound. Carlgren's (1949) catalog lists 16 nominal species in the genus, including, questionably, E. japonica, which has since been found valid (Dunn 1975b). All occur in austral and boreal polar and cold temperate seas. At least seven brood their young externally, a character Verrill (1869) used in defining the genus because the only species he knew then, E. prolifera, does so. At least one species listed by Carlgren (1949) broods internally.

Any externally brooding intertidal actinian in the northeastern Pacific has been called Epiactis prolifera, a species exhibiting considerable morphological and behavioral variability (Dunn 1977; R. N. Mariscal, personal communication). This makes intuitive biological sense since development of these anemones is direct, and they therefore lack a dispersal stage (Dunn $1975 b$ ). However, generally large and invariably longitudinally striped, externally brooding specimens of Epiactis that occur at least from Bamfield south to Coos Bay, are dioecious, in contrast to the gynodioecy (Dunn 1975a) of E prolifera. The two differ as well in brooding strategy.

A second eastern Pacific species of Epiactis, E. ritteri, was described from Alaska by Torrey (1902). Carlgren (1934, p. 351 ) created the genus Cnidopus for it because of "the very numerous nematocysts present at the sides of the protuberances and between them in the lowest part of the column." This species ranges to central California, where it broods its young internally (Hand and Dunn 1974), as it does on the west coast of Vancouver Island (personal observations).
"Log caves" (surge channels roofed over by drift logs) on the west side of San Juan Island, Washington, U.S.A., contain not only anemones typical of the sheltered Pacific coast, but two previously undescribed, internally brooding species. One has been named Aulactinia incubans Dunn, Chia, and Levine, 1980. The second, initially identified as Cnidopus ritteri, a species we have not found in the San Juan Islands, is another new species of Epiactis.

\section{Materials and methods}

Sea anemones were studied alive in the intertidal zone on San Juan Island $\left(48^{\circ} 32^{\prime} \mathrm{N}, 123^{\circ} 05^{\prime} \mathrm{W}\right)$ and at the University of Washington Friday Harbor Laboratories. Descriptions are based on examination of more than 25 specimens of each species.

Animals to be preserved were relaxed with chloral hydrate or $\mathrm{MgCl}_{2}$ in sea water, then fixed in $10 \%$ formalin. Many were bisected longitudinally; paraffin sections $5-8 \mu \mathrm{m}$ thick were cut crosswise in the central body and longitudinally at the margin from one half. Slides were stained with Mallory-Heidenhain or hematoxylin and eosin.

Cnidae were measured in tissue smears from living and preserved specimens; not all tissues of each individual were examined. For data on cnidae (Table 1), $N$ is the ratio of the number of animals in which a particular kind of cnida was found to the total number examined for that tissue type, and $n$ is the number of cnidae measured; measurements in parentheses are of single capsules that fell outside the usual range.

\section{Epiactis lisbethae n.sp.}

\section{Description}

Pedal disc

Adherent; circular to irregularly ovoid; as great as $80 \mathrm{~mm}$ diameter, commonly $50 \mathrm{~mm}$; typically about twice as wide as 


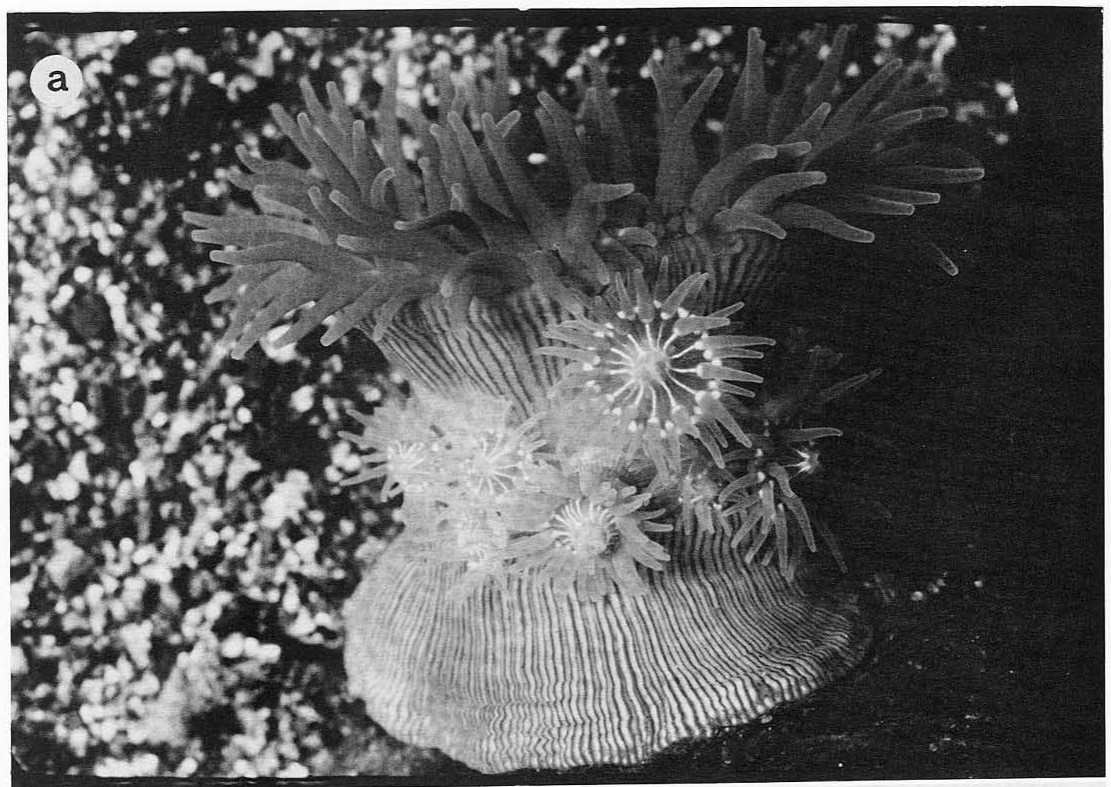

b

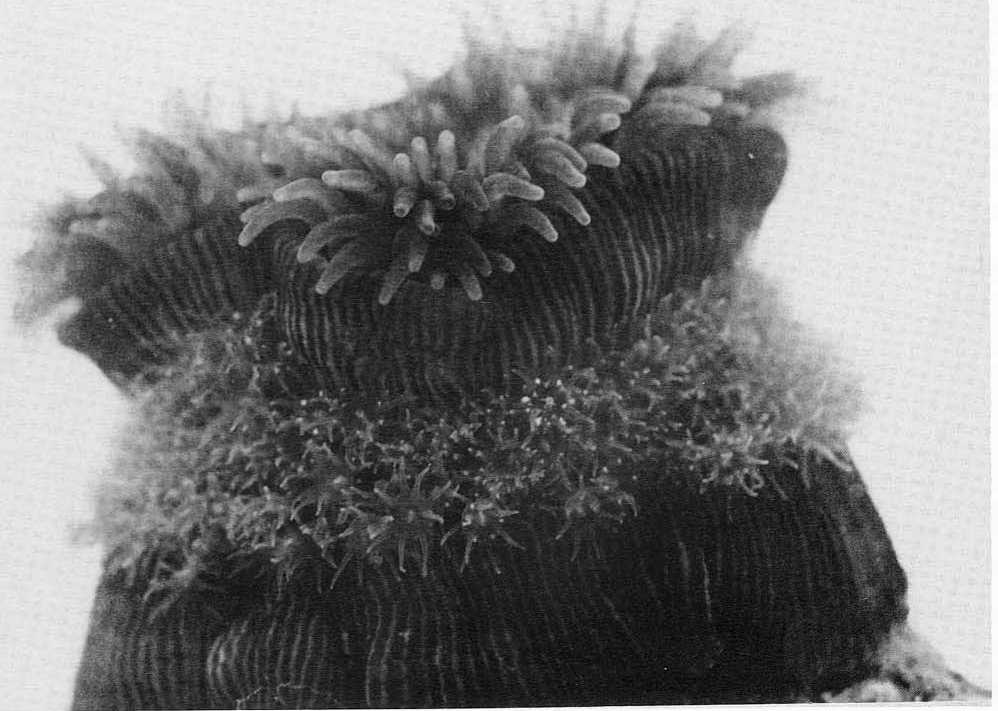

FIG. 1. Epiactis lisbethae. Tentacles of adults are contracted; in expansion they are sinuous, several times longer, and the marginal ones hang over the edge of the oral disc, obscuring brooded young. Note longitudinal striping, and position of young. (a) Specimen from San Juan Island, with few older juveniles. Photograph by R. N. Mariscal. (b) Specimen from Bamfield, with many young juveniles. 


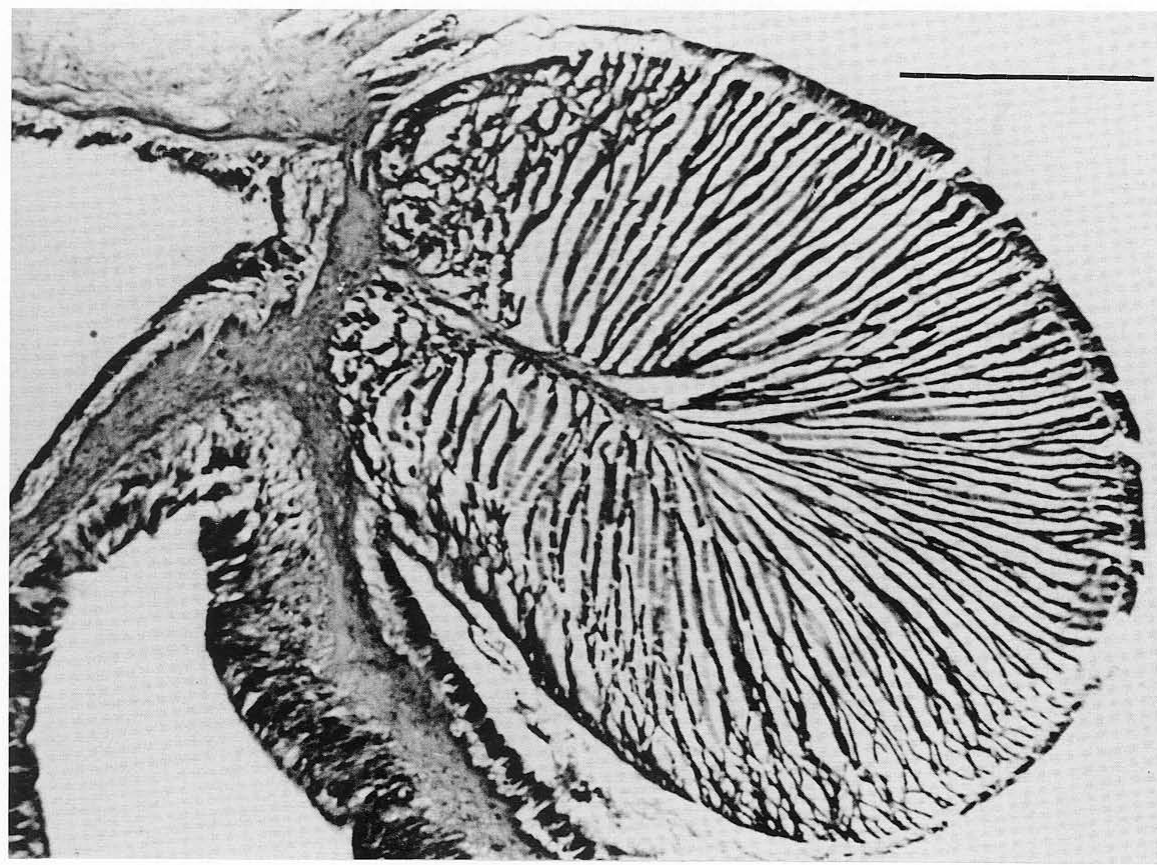

FIG. 2. Sphincter muscle of Epiactis lisbethae (paratype: SBMNH 33890). Scale bar $=250 \mu \mathrm{m}$.

column. Edge of preserved animals often ruffled, probably because of contraction. In life, radially striped alternately red (rarely green, brown, or orange) along mesenterial insertions and grey or white between them, converging to solid red (or green or orange) center; stripes continuations of those along column. Edge of some appears scalloped because of bulging between mesenterial insertions.

\section{Column}

Cylindrical; smooth; of equal width throughout except where pedal end flares; length about equal to pedal disc width. Boxy when fully contracted. Fosse deep (1-2 mm). Longitudinal stripes evident in life (Fig. 1) except in some light-hued individuals, alternately bright to deep red (rarely green, brown, or orange) along mesenterial insertions and grey to blue-grey, grey-green, or white along endocoels and exocoels; of approximately equal width; may be less prominent distally. One to three vertically arrayed red spots often present at proximal end of some lighter stripes.

Up to several hundred young anemones, all of similar size and color (typically pinkish on red, brown, or green individuals, orange on parents of that color), attached to middle part of column, frequently in band five or more young deep (Fig. $1 b$ ). Some may be hidden in groove near limbus that can form in retracted specimens. Only females brood.

\section{Oral disc and tentacles}

Oral disc flat, about same diameter as pedal disc, typically deep red to translucent tan. Small, central, elongate, lipless mouth may be bordered by white or brown; usually on oral cone.
White spot sometimes marks distal end of each siphonoglyph. Mesenterial insertions often marked by red, especially prominent around outer tentacles.

Tentacles sinuous, sticky, occupy marginal half; typically hang over margin (i.e., not held erect) in life. All 96 (? or more) about equal length or inner slightly longer, to $20 \mathrm{~mm}$ long, tapering from $2+\mathrm{mm}$ basal diameter to blunt, perforate, pale end. Tentacle color that of oral disc when contracted, lighter hue when expanded; white splotch or chevron at base on oral side of outer and (or) inner tentacles, rarely tentacle base ringed with white; 48 inner tentacles with white or pink line from base nearly to oral cone, generally boldest over primary and secondary endocoels, more subdued over higher orders; those on directive axis extending onto oral cone. Longitudinal tentacle muscles ectodermal.

\section{Internal anatomy}

Actinopharynx pink, deeply sulcate, with two prominent, symmetrical, intense pink or white siphonoglyphs.

Sphincter circumscript endodermal, arising from marginal side at proximal end of fosse; pinnate with lamellae symmetrical about main axis (Fig. 2).

Mesenteries regularly arrayed, up to five cycles observed. Those of first two cycles complete. Marginal stomata large; oral stomata not seen. Retractor muscles strong (Fig. 3); musculature diffuse with all lamellae about equal length, poorly developed to virtually absent on highest order or two. Parietobasilar muscles wide with generally narrow detached pennon.

Complete mesenteries sterile. Those of highest three orders 


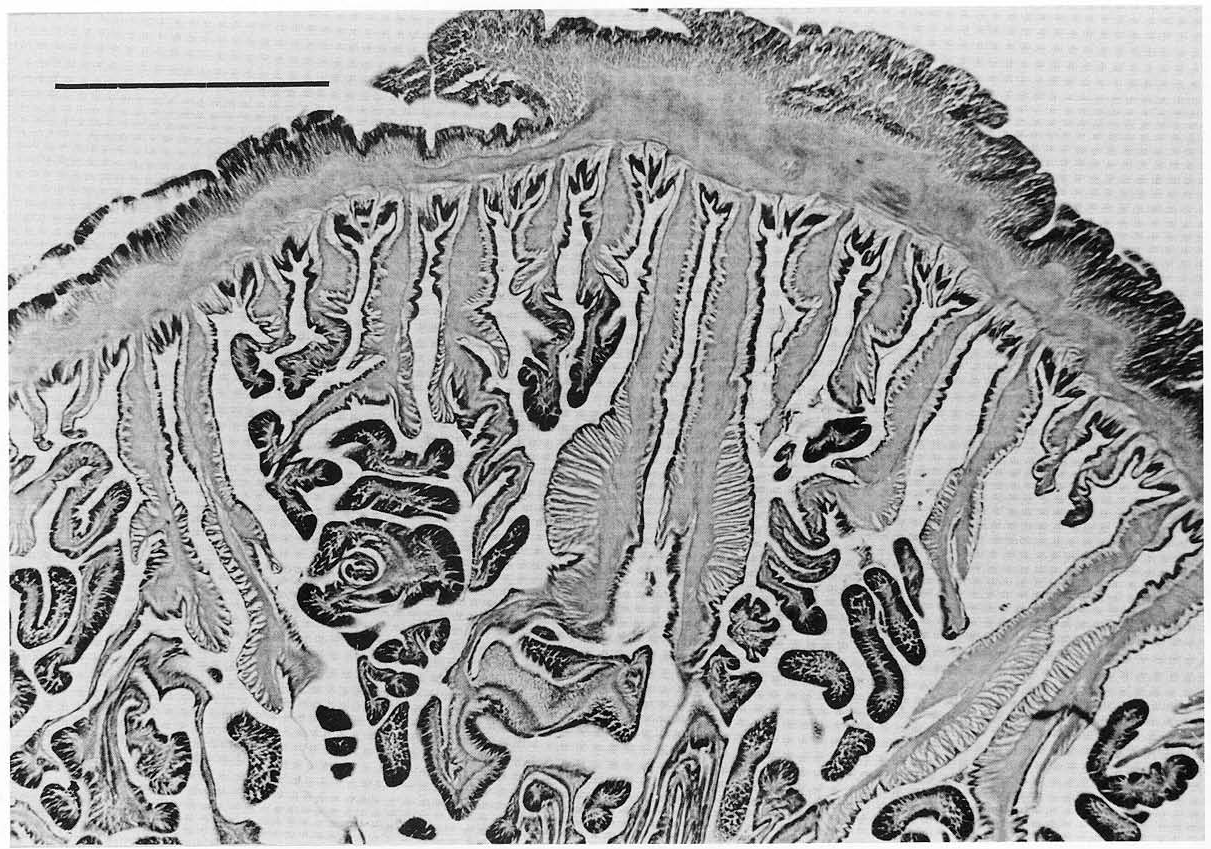

FIG. 3. Cross section through midcolumn of Epiactis lisbethae (CAS 035146). Scale bar $=1 \mathrm{~mm}$.

fertile, or ultimately sterile if poorly developed. Sexes separate; ova to $500 \mu$ m diameter in section; with trophonemata (Fig. 4).

\section{Cnidom}

Spirocysts, basitrichous isorhizas (basitrichs), holotrichous isorhizas (holotrichs), microbasic $p$-mastigophores.

\section{Size and distribution of cnidae}

See Table 1 . The letter following each cnida type corresponds to illustration of it in Fig. 5.

\section{Sexuality}

Relationship between size and sexuality of 25 sectioned individuals of all sizes collected in 1979 and 1982 is shown in Table 2. The excess of females is probably due to sampling bias: since only females brood, and brooders were of particular interest, more brooders than nonbrooders were collected. With an average pedal disc diameter of $16.5 \pm 4.1 \mathrm{~mm}$, sterile individuals were smaller than sexually mature ones. Females averaged $41.2 \pm 15.8 \mathrm{~mm}$ and males $38.3 \pm 10.3 \mathrm{~mm}$; these diameters are not significantly different $(t=0.4127)$. No hermaphrodites were found, and there is no evidence of sex change.

\section{Habitat, range, and natural history}

On the exposed (west) side of San Juan Island, these anemones occur as high as $+0.5 \mathrm{~m}$, typically attached to the underside of boulders. On the east side of the island, rare specimens are attached to eelgrass. More common are anemones floating free in still waters; presumably these have detached from eelgrass. In Barkley Sound, Vancouver Island, they are mostly subtidal, occurring to $10 \mathrm{~m}$ on rocks and kelp in areas of vigorous surge.

Epiactis lisbethae is currently known from the intertidal zones of San Juan Island and the vicinity of Coos Bay, Oregon, and subtidally in Washington (R. N. Mariscal, personal communication), and the west coast of Vancouver Island. We have not found it in the northern California littoral despite numerous searches.

Specimens of this anemone are sensitive, withdrawing rapidly but reexpanding rather readily as well. However, when water is poured from a container in which one is attached, its tentacles droop rather than retract. Captive animals tend to move onto the sides of containers and aquaria.

\section{Etymology}

Epiactis lisbethae honors Dr. Lisbeth Francis, a long-time student of actinians and investigator at Friday Harbor Laboratories, whose keen eye first perceived many of the subtle differences between this anemone and $E$. prolifera.

\section{Type locality and specimens}

HOLOTYPE: Female brooding more than 300 young, brown and white striped in life; deposited in Department of Invertebrate Zoology, California Academy of Sciences (CAS 031667); collected 10 May 1982, by D.G.F. and F.-S.C.

TYPE LOCALITY: Mar Vista, False Bay, San Juan Island.

PARATYPES: At the California Academy of Sciences, one-half male bisected longitudinally (CAS 031669), with histological slides; collected 7 August 1979, Cattle Point, San Juan Island. 


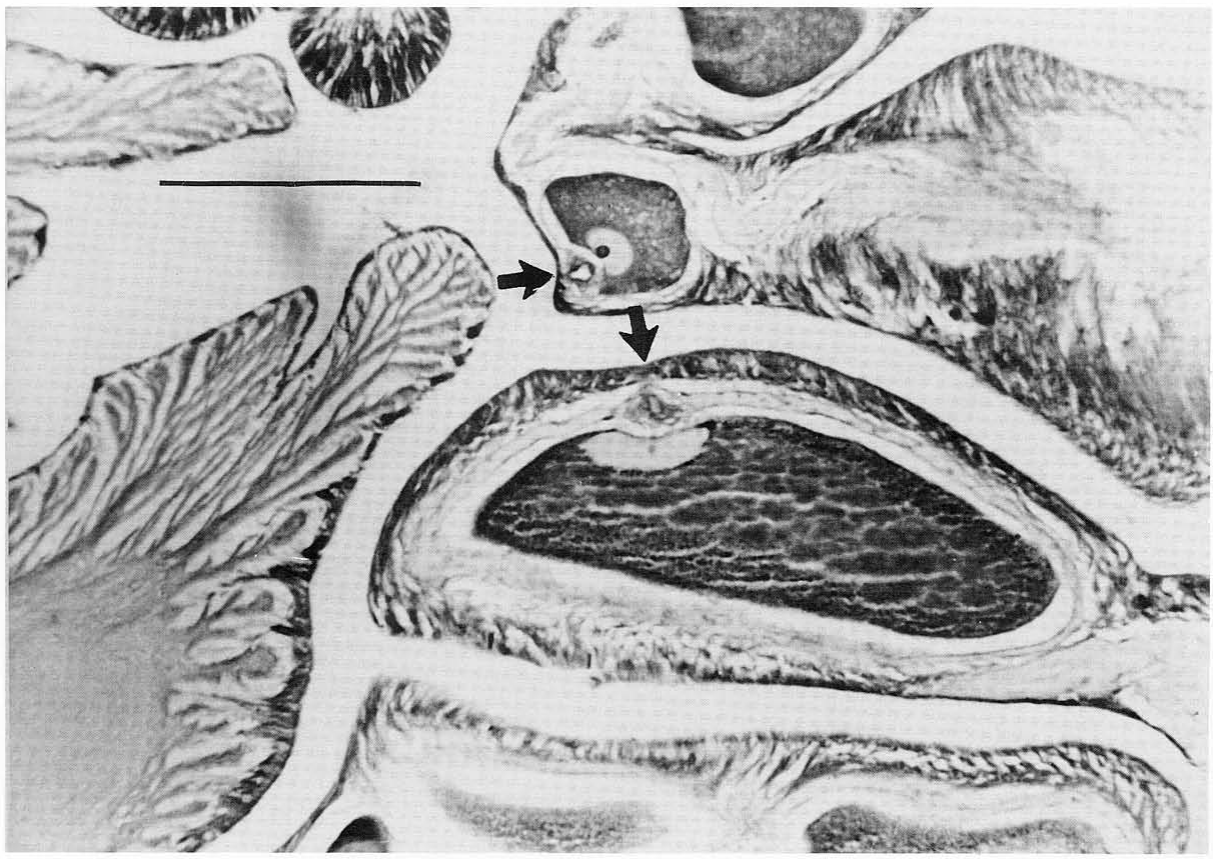

FIG. 4. Ova with trophonemata (arrows) in Epiactis lisbethae (CAS 052758). Scale bar $=250 \mu \mathrm{m}$.

Two and one-half dissected females (CAS 031668), with histological slides of two of them, collected 10 May 1982, at type locality. At the British Columbia Provincial Museum, two brooding females (BCPM 983-1578-1), collected 10 May 1982, at type locality. At the Santa Barbara Museum of Natural History, half of a longitudinally bisected, nonbrooding female, with histological slides, collected 6 August 1979, at Grandmother's Cove, American Camp, San Juan Island (SBMNH 33890). At the U.S. National Museum of Natural History, three-quarters of a very large, brooding female (USNM 61274), with histological slides, collected 10 May 1982, at type locality.

\section{Description}

Epiactis fernaldi n.sp.

\section{Pedal disc}

Adherent, circular, diameter somewhat greater than that of column, to $45 \mathrm{~mm}$ but typically $20 \mathrm{~mm}$. Colorless or uniform color of lighter hue than column, with dark mesenterial insertions.

\section{Column}

Cylindrical, of uniform diameter; height about half pedal disc diameter; smooth. Lacking distinguishing markings; green, dark orange, brick red, or deep mustard color, generally solid but occasional individuals with splotches of deeper or lighter hue. Mesenterial insertions may be visible in expansion. Fosse present but not conspicuous.

\section{Oral disc and tentacles}

Oral disc flat, about equal to or somewhat narrower or broader than pedal disc. Mouth small, round, lipless; oral cone transitory. Color typically solid but not always same as that of column; dark (usually reddish) mesenterial insertions sometimes visible.

Tentacles occupy outer half, central ones held erect. All equal length, to about $8 \mathrm{~mm}$; taper uniformly or only at end to blunt point; base about $2 \mathrm{~mm}$ diameter, so stubby. Translucent in expansion; color that of oral disc or greyish, uniform except each outer tentacle may have white blotch or band or simply lighter hue at base on oral face. Up to 85 counted. Longitudinal muscles ectodermal, circular endodermal.

\section{Internal anatomy}

Actinopharynx pink or brown. Two symmetrical siphonoglyphs.

Sphincter circumscript endodermal, arising from marginal side at proximal end of fosse; secondary lamellae longer on marginal than oral side (Fig. 6). In one specimen (BCPM 983-1579-1), main lamella bifurcated at distal end.

Mesenteries regularly arrayed; most animals with four cycles, rarely five; those of first two or three complete. Marginal stomata large, no oral stomata seen. Wide retractor muscles diffuse, well developed (Fig. 7), with all primary lamellae about equal length and few secondary. Parietobasilar muscles wide with short detached pennon (Fig. 7).

Secondary and tertiary mesenteries fertile; fourth order also in individuals with five cycles. Sperm and eggs in separate mesenteries or the same one; each ovum (orange in color) with trophonema, to $375 \mu \mathrm{m}$ diameter in section. 
TABLE 1. Cnidae of the four North American species of Epiactis: measurements $(\mu \mathrm{m})$ of the three species found on San Juan Island, Washington, and published values for E. prolifera and E. ritteri

\begin{tabular}{|c|c|c|c|c|c|}
\hline & \multicolumn{3}{|c|}{ San Juan Island species } & \multirow{2}{*}{$\begin{array}{l}\text { E. prolifera } \\
\text { (Hand 1955) }\end{array}$} & \multirow{2}{*}{$\begin{array}{c}\text { E. ritteri } \\
\text { (Hand and } \\
\text { Dunn 1974) }\end{array}$} \\
\hline & E. lisbethae & E. fernaldi & E. prolifera & & \\
\hline \multicolumn{6}{|l|}{ Tentacles } \\
\hline Spirocysts (A) & $17.0-36.0 \times 2.5-4.0$ & $13.0-28.0 \times 2.0-3.5$ & $16.0-40.0 \times 2.5-5.0$ & $13.0-33.5 \times 2.0-4.0$ & $22.0-38.0 \times 2.5-3.0$ \\
\hline$n$ & 52 & 56 & 65 & 64 & 43 \\
\hline$N$ & $7 / 7$ & $9 / 9$ & $9 / 9$ & $?$ & $?$ \\
\hline Basitrichs (B) & $11.0-16.0 \times 2.2-2.8$ & $9.0-14.0 \times 2.2-2.8^{*}$ & $13.0-15.0 \times 2.0-2.5^{\dagger}$ & None & None \\
\hline$n$ & 6 & 7 & 6 & & \\
\hline$N$ & $4 / 7$ & $3 / 9$ & $3 / 9$ & & \\
\hline Basitrichs (C) & $20.0-32.0 \times 2.5-3.5(4.0)$ & $18.0-25.5 \times 2.0-3.0$ & $(20.0) 25.0-35.0 \times 2.7-4.2$ & $19.5-30.5 \times 2.0-3.0$ & $19.0-32.0 \times 2.5-3.0$ \\
\hline$n$ & 64 & 54 & 66 & 72 & 45 \\
\hline $\mathrm{N}$ & $7 / 7$ & $9 / 9$ & $9 / 9$ & $?$ & $?$ \\
\hline Holotrichs (D) & $25.0-31.0 \times 3.0-4.2 *$ & $(16.0) 18.0-25.5 \times 2.5-4.0^{*}$ & $23.0-30.0 \times 3.2-4.5 \dagger$ & None & Nonẹ \\
\hline n & 14 & 47 & 27 & & \\
\hline$N$ & $4 / 7$ & $8 / 9$ & $5 / 9$ & & \\
\hline \multicolumn{6}{|l|}{ Actinopharynx } \\
\hline Basitrichs (B) & $13.0-15.0 \times 2.0-2.8$ & None & None & None & $15.0-20.0 \times 2.0-2.5$ \\
\hline$n$ & 7 & & & & 12 \\
\hline$N$ & $2 / 4$ & & & & $?$ \\
\hline Basitrichs (E) & $27.0-38.0 \times 3.2-4.2$ & $19.0-30.0 \times(2.5) 3.0-4.0$ & $28.0-34.0 \times 3.2-4.5$ & $20.0-34.0 \times 2.0-3.0$ & $24.0-33.0 \times 2.9-3.8$ \\
\hline$n$ & 26 & 20 & 27 & 57 & 29 \\
\hline$N$ & $4 / 4$ & $3 / 3$ & $4 / 4$ & $?$ & $?$ \\
\hline \multicolumn{6}{|l|}{ Microbasic } \\
\hline p-mastigophores $(\mathrm{F})$ & $20.0-27.0 \times 4.2-5.5$ & None & $19.0-25.0(27.0) \times 4.5-6.0$ & $15.5-23.0 \times 4.5-5.0$ & None \\
\hline$n$ & 19 & & 15 & 63 & \\
\hline$N$ & $4 / 4$ & & $3 / 4$ & $?$ & \\
\hline \multicolumn{6}{|l|}{ Mesenterial filaments } \\
\hline Basitrichs $(\mathrm{G})$ & $12.0-24.0 \times 2.0-3.2$ & $12.0-23.0 \times 2.0-3.2(3.7)$ & $13.0-18.0 \times 2.0-3.0$ & $11.0-31.0 \times 2.0-3.0$ & $14.0-19.0 \times 2.0-2.5$ \\
\hline$n$ & 39 & 29 & 27 & 70 & 11 \\
\hline$\ddot{N}$ & $6 / 6$ & $6 / 8$ & $5 / 6$ & $?$ & $?$ \\
\hline Basitrichs $(\mathrm{H})$ & $18.0-27.0 \times 3.8-5.5$ & $19.0-24.0 \times(3.0) 3.5-4.8$ & $(17.0) 18.0-27.0 \times 2.5-3.8(4.7)$ & None (probably & $20.0-34.0 \times 4.0-5.0$ \\
\hline$n$ & 37 & 38 & 14 & combined with & 23 \\
\hline$N$ & $6 / 6$ & $8 / 8$ & $4 / 6$ & previous category) & $?$ \\
\hline \multicolumn{6}{|l|}{ Microbasic } \\
\hline p-mastigophores (I) & $17.0-23.0 \times 4.0-6.0$ & $16.0-26.0 \times 3.5-5.2(6.0)$ & $15.0-23.0 \times 3.8-5.5$ & $\begin{array}{c}17.0-28.0 \times 3.5-4.5 \\
\text { and }\end{array}$ & $21.0-27.0 \times 4.5-5.5$ \\
\hline & & & & $16.0-24.0 \times 3.5-5.0$ & \\
\hline$n$ & 35 & 51 & 37 & 113 & 21 \\
\hline N & $6 / 6$ & $8 / 8$ & $6 / 6$ & $?$ & $?$ \\
\hline \multicolumn{6}{|l|}{ Column } \\
\hline Basitrichs $(\mathrm{J})$ & $17.0-23.0 \times 2.5-3.5$ & $(10.5) 13.5-21.0 \times 2.2-3.2$ & $15.0-23.0(27.0) \times 2.5-3.8(4.5)$ & $11.0-23.0 \times 2.0-3.0$ & $14.4-26.0 \times 1.9-2.5$ \\
\hline$n$ & 40 & 68 & 57 & 57 & 57 \\
\hline N & $6 / 6$ & $9 / 9$ & $7 / 7$ & $?$ & $?$ \\
\hline Holotrichs (D) & None & None & $28.0-30.0 \times 3.8$ & None & $26.9-42.0 \times 3.8-5.0$ \\
\hline$n$ & & & 2 & & 82 \\
\hline$N$ & & & $1 / 7$ & & $?$ \\
\hline
\end{tabular}

NorE: Capital letters refer to illustrations in Fig. $5, n$, number of cnidae measured: $N$, ratio of number of animals in which particular cnida was found/total number examined for that tissue type. Measurements in parentheses are of single capsules that were outside the usual range.

† Mainly outer tentacles. 


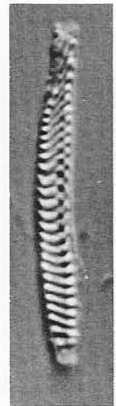

A

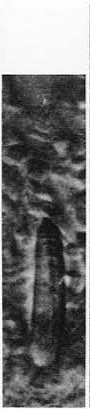

B

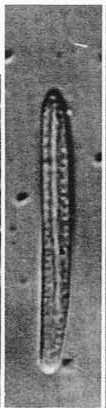

C

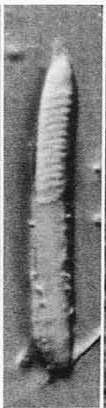

D

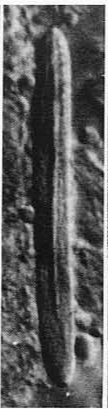

E

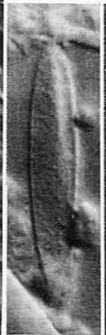

$\mathbf{F}$

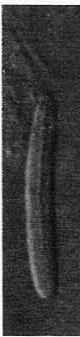

G

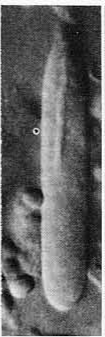

H

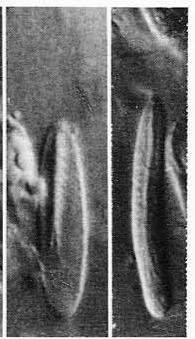

I J

FIG. 5. Cnidae of Epiactis lisbethae and Epiactis fernaldi. Letters refer to categories in Table 1. Scale bar $=10 \mu \mathrm{m}$.

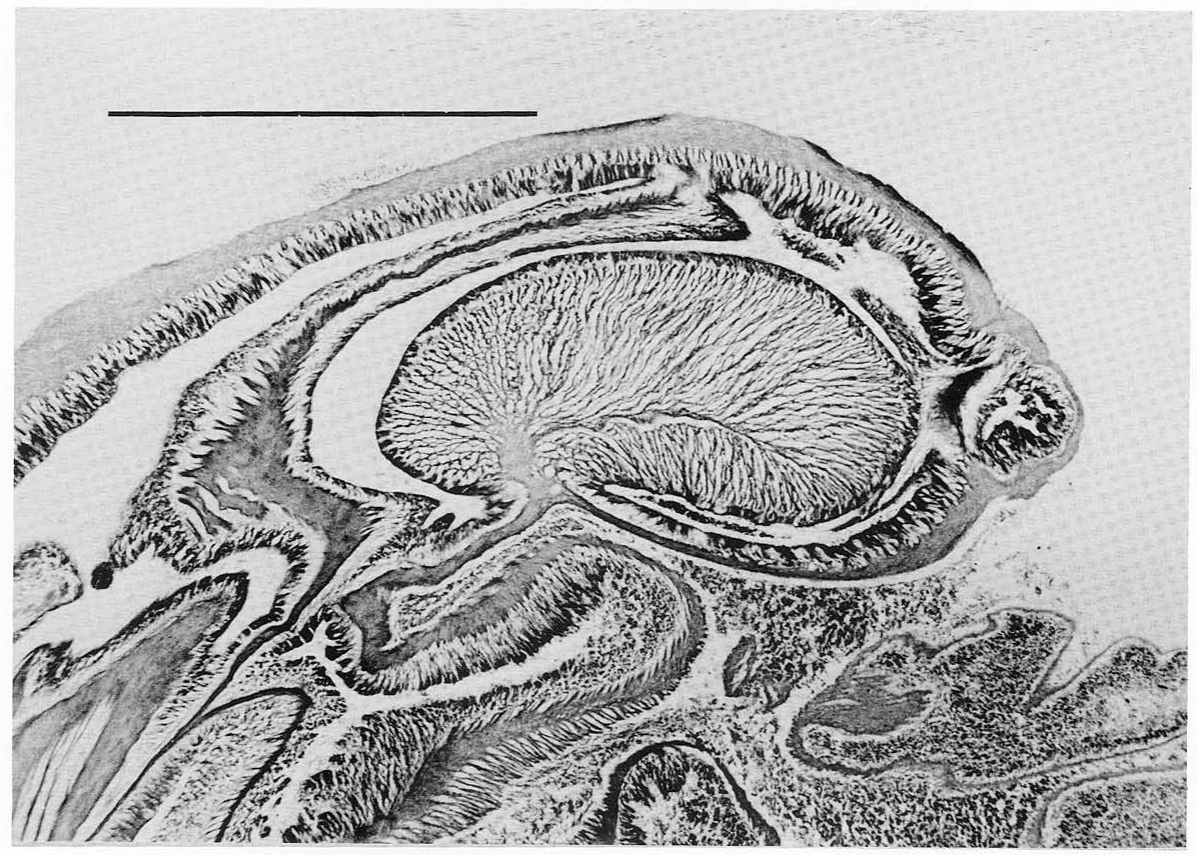

FIG. 6. Sphincter muscle of Epiactis fernaldi (holotype: CAS 031671). Scale bar $=1 \mathrm{~mm}$.

\section{Cnidom}

Spirocysts, basitrichous isorhizas (basitrichs), holotrichous isorhizas (holotrichs), microbasic $p$-mastigophores.

Size and distribution of cnidae

See Table 1 . The letter following each cnida type corresponds to illustration of it in Fig. 5.

\section{Sexuality}

All except 3 of 15 individuals of known sexuality were hermaphroditic. Their average pedal disc diameter was $23.5 \pm$ $9.60 \mathrm{~mm}$, ranging from 12 to $45 \mathrm{~mm}$. The two sterile individuals were 8 and $20 \mathrm{~mm}$, and the other, $22 \mathrm{~mm}$ in size, contained a very few ova. The one brooded young that was sectioned 


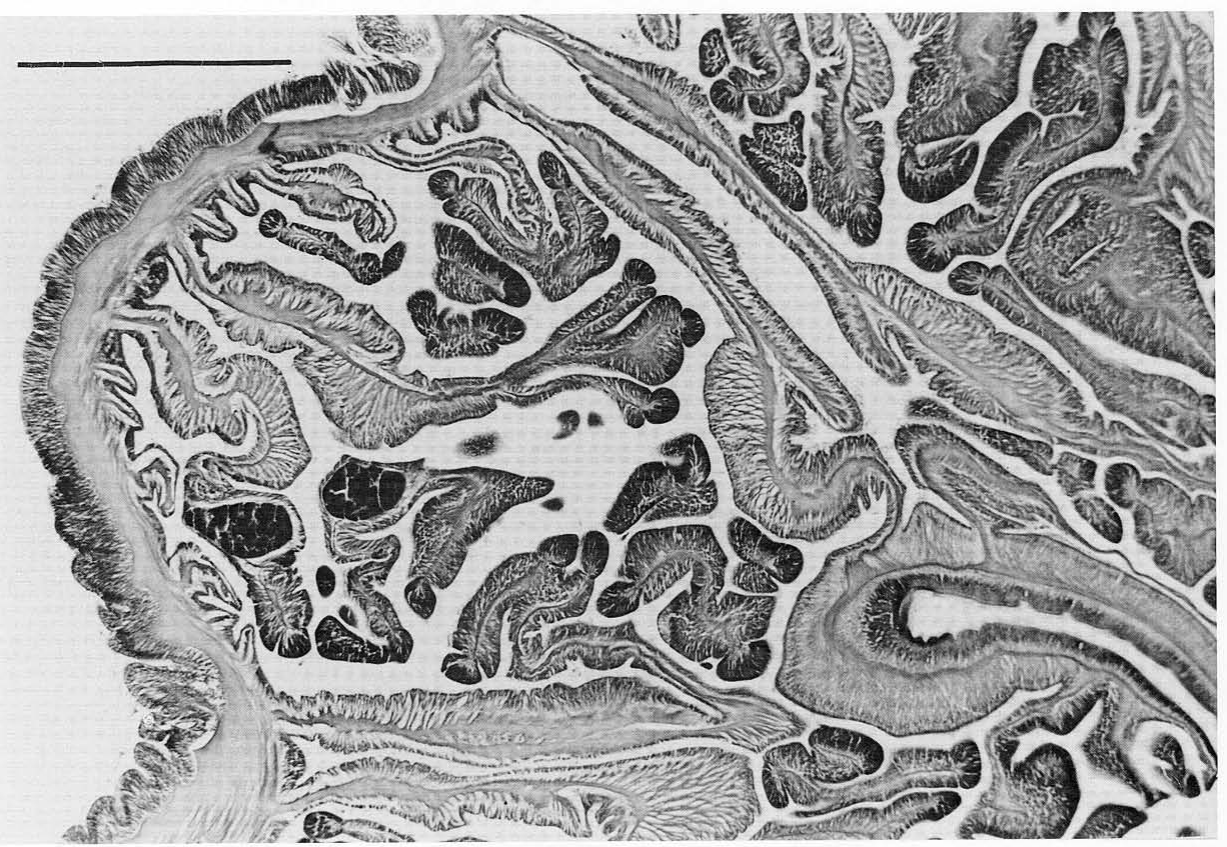

FIG. 7. Cross section of Epiactis fernaldi (paratype: CAS 031672). Scale bar $=1 \mathrm{~mm}$.

contained only ova. This suggests that female gonads develop before male ones in Epiactis fernaldi, but that virtually all sexually mature members of the population are hermaphroditic.

Young are brooded internally. No more than five were recovered from any anemone. The average pedal disc diameter of the four brooding individuals, all hermaphrodites, was $30 \pm$ $5.48 \mathrm{~mm}$. This does not differ significantly from the diameter of hermaphroditic individuals $(t=1.2685)$.

\section{Habitat, range, and natural history}

This species is known only from very sheltered, rocky intertidal areas in caves and surge channels roofed over by drift logs on the west side of San Juan Island, where it lived attached to rocks quite high intertidally. When the site was revisited in May and June 1985, the drift logs were gone and no specimens of Epiactis fernaldi could be found.

This is a sensitive animal, withdrawing readily and reexpanding reluctantly.

\section{Etymology}

Epiactis fernaldi honors the late Dr. Robert Fernald, Professor of Zoology at the University of Washington and Director of Friday Harbor Laboratories, whose enthusiasm for marine invertebrates was contagious and in whose laboratory this anemone was first seen.

\section{Type locality and specimens}

HOLOTYPE: Nonbrooding hermaphrodite, reddish brown in life; longitudinally bisected with histological slides; deposited in Department of Invertebrate Zoology, California Academy of
TABLE 2. Relationship between size and sexuality in Epiactis lisbethae

\begin{tabular}{rccc}
\hline \hline $\begin{array}{c}\text { Pedal disc } \\
\text { diameter }\end{array}$ & $\begin{array}{c}\text { No. } \\
\text { sterile }\end{array}$ & $\begin{array}{c}\text { No. } \\
\text { male }\end{array}$ & $\begin{array}{c}\text { No. } \\
\text { female }\end{array}$ \\
\hline $0-20 \mathrm{~mm}$ & 4 & 0 & 0 \\
$21-35 \mathrm{~mm}$ & 0 & 3 & 6 \\
$36-50 \mathrm{~mm}$ & 0 & 3 & 7 \\
$51-76 \mathrm{~mm}$ & 0 & 0 & 2 \\
\hline
\end{tabular}

Sciences (CAS 031671); collected 28 July 1979, by D.G.F. and Lisbeth Francis.

TYPE LOCALITY: "Log cave," west side Cattle Point, San Juan Island.

PARATYPES: At the California Academy of Sciences, one whole individual (CAS 031670), collected 15 August 1979, at type locality; a longitudinally bisected female (CAS 031672) with histological slides, collected 15 August 1979, at type locality; a longitudinally bisected hermaphrodite (CAS 031674) with histological slides, collected 25 July 1979, at type locality. At the British Columbia Provincial Museum, a longitudinally bisected hermaphrodite (BCPM 983-1579-1) with histological slides, collected 15 August 1979, at type locality. At the Santa Barbara Museum of Natural History, a longitudinally bisected hermaphrodite (SBMNH 33891) with histological slides, collected 15 August 1979, at type locality. At the U.S. National 
Museum of Natural History, a longitudinally bisected female with histological slides USNM 61273), collected 25 July 1979, at type locality.

\section{Discussion}

The San Juan Island population of large, externally brooding specimens of Epiactis with prominent longitudinal stripes was initially regarded as an ecotype of $E$. prolifera. Living in quiet waters, these anemones seemed analogous to the large green specimens in Bodega Harbor, California (Dunn 1977). Indeed, their cnidae conform exactly to those of $E$. prolifera. However, they are gonochoric, in contrast to specimens of E. prolifera, which are gynodioecious hermaphrodites (Dunn 1975a). A specimen of $E$. prolifera typically carries offspring of various sizes, a reflection of prolonged breeding (Dunn 1975b), whereas production of young by $E$. lisbethae is highly seasonal, for brooding individuals cannot be found during late summer. Indeed, a female probably spawns once a season, to judge by the uniform size of brood mates.

Animals that resemble Epiactis prolifera as known from the outer coast of California (i.e., that are smaller, brood no more than 40 young, generally of various sizes, in a single ring, and lack longitudinal column stripes) were also collected on San Juan Island. The population revealed a pattern of gynodioecious hermaphroditism, with sex change occurring at precisely the same sizes as in the California population of $E$. prolifera studied by Dunn (1975a). Moreover, large green specimens of E. prolifera, like those found in Bodega harbor (Dunn 1977), live on algae in Roche Harbor, San Juan Island.

Verrill's (1869, p. 492) statement that "all except very small specimens [bear] a circle of young of various sizes, which vary in number from very few up to 30 or 40 . When most numerous they are closely crowded, somewhat in two rows" confirms that his original description of Epiactis prolifera referred to the species that has been known by that name. Similarly, the anemone recommended by Bovard and Osterud (1918) as a source of embryological material in Puget Sound was indeed $E$. prolifera since "all sizes of these young are obtainable all summer" (p. 129).

The cnidae we term holotrichs were originally called atrichs, for their spines are at the limits of light microscope resolving power (Bigger 1976, 1982). (There does seem to be a truly atrichous nematocyst as well, found at least in cubomedusae (Rifkin and Endean 1983).) Holotrichs are now established as occurring in Epiactis; indeed, at least some specimens of the type species of the genus possess them. Thus, Cnidopus cannot be distinguished by that feature. Holotrichs are present in the acontiate anemones Metridium senile and Haliplanella luciae only in catch (=fighting) tentacles (Purcell 1977; Watson and Mariscal 1983), which can be induced to develop under certain conditions. They are also characteristic of acrorhagi, structures used in agonistic encounters by certain genera of actiniid actinians (Francis 1973; Bigger 1982). Thus, this category of cnidae seems inducible and systematic weight cannot be attached to its presence or absence. Whether holotrichs in Epiactis serve an agonistic function bears further study, for their occurrence in tentacles is apparently confined to the margins. This probably accounts for their having been overlooked until now. For similar reasons, Siebert and Spaulding (1976) added "atrichs" to the definition of Cribrinopsis.

The other feature purportedly distinguishing the genus Cnidopus is the presence of adhesive patches on the lower column. This alone would not merit generic distinction for its possessor. In all other respects, $C$. ritteri, type species of the genus, conforms to the criteria for Epiactis, to which Torrey (1902) originally assigned it, and to which we hereby return it. Two other species attributed to Cnidopus (Hand and Dunn 1974) should be examined to determine whether they, too, fit the definition of Epiactis.

The only significant difference in cnidae among these species is holotrichs in the column of Epiactis ritteri, but that is not entirely diagnostic since one specimen of $E$. prolifera examined from the San Juan Islands contained them, as do rare individuals in central California (personal observation; C. Hand, personal communication). Actinopharynx basitrichs are not consistently found in $E$. lisbethae (whether because they are truly absent or because they are rare or patchy), so are not diagnostic either. Hand (1955) reported spirocysts in the column of E. prolifera identical in size with those of the tentacles. Three specimens of E. ritteri from Bamfield, British Columbia, contained cnidae, in agreement with published figures for the species (Hand and Dunn 1974) except that some in most categories were slightly smaller than had previously been known for the species, one animal had a couple of small basitrichs in its tentacles, and the actinopharynx of one contained some microbasic p-mastigphores.

Thus the two externally brooding species are separable by color pattern, maximum size attained, sexuality, and timing of reproduction. They also differ in behavior (L. Francis, personal communication), especially with respect to feeding (R. N. Mariscal, personal communication). When a specimen of $E$. prolifera feeds, it typically contracts its entire oral disc, whereas in $E$. lisbethae, only those tentacles actually contacted by food infold. Specimens of $E$. prolifera will "ingest a wide variety of inert and plant material" (Lenhoff 1965, p. 1003), whereas those of E. lisbethae make no attempt to do so. It would be impossible, with current knowledge, to assign to either species a preserved, small, nonbrooding, female from Oregon, Washington, or British Columbia. The external brooder referred to as Epiactis prolifera by Uchida (1934), and since established to be $E$. japonica (see Dunn 1975b), is also gonochoric and reproduces seasonally. It is distinguishable from $E$. lisbethae by the presence of "egg-pits," its variable and unusual colors and patterning, and its assumption of a nearly flat profile in contraction (Uchida 1934).

Hermaphroditism is frequently associated with brooding and with small size (Ghiselin 1969). Presumably brood space is at a sufficient premium in Epiactis prolifera that every individual must brood, which has led to some members of the population being hermaphroditic (Dunn 1975a). In the larger E. lisbethae, sufficient propagules to maintain the species seem to survive with only a portion of the population brooding, each brooder sheltering considerably more young than are brooded by each individual of $E$. prolifera.

The adhesive spots and associated holotrichs in the lower column of specimens of Epiactis ritteri readily separate that species from the other internal brooder. The column of a light-hued individual of $E$. ritteri is bespeckled with small, dark, and evenly but densely distributed spots. Grains of sand also adhere to the lower column; there is no debris on the column of an anemone of $E$. fernaldi. The peripheral pedal disc of large individuals of $E$. ritteri is deep blue-green, but this is also true in some specimens of E. prolifera and E. lisbethae as well as Actinia equina (e.g., see Fischer 1889, p. 295), so it simply may be a correlative of large size in a variety of sea anemones. In contraction, specimens of $E$. ritteri become exceedingly flat, 
whereas those of $E$. fernaldi are domed. Internal anatomy is virtually identical in the two except that the former is gonochoric and the latter hermaphroditic. Once again, small body size is a correlative of hermaphroditism.

With the addition of two new species of Epiactis, synonymization of Cnidopus with Epiactis, and other recent taxonomic changes in the genus (Dunn 1975b, 1983), it now contains 19 nominal species, making it one of the larger genera of sea anemones.

\section{Acknowledgments}

We are grateful to Ron Koss and Ron Seward for technical assistance, and to Barbara Weitbrecht for preparation of the figures. James Dalby, Jr., provided information on specimens from Bamfield. Richard N. Mariscal contributed field observations on feeding behavior, Fig. $1 a$, and useful editorial comments. Thanks are also due to Eugene Kozloff for editorial suggestions. This research was supported by a grant from the Natural Sciences and Engineering Research Council of Canada to F.-S. Chia.

BIGGER, C. H. 1976. The acrorhagial response in Anthopleura krebsi: intraspecific and interspecific recognition. In Coelenterate biology and behavior. Edited by G. O. Mackie. Plenum Press, New York. pp. 127-136.

1982. The cellular basis of the aggressive acrorhagial response of sea anemones. J. Morphol. 173: 259-278.

Bovard, J. F., and H. L. Osterud. 1918. Partial list of the animals yielding embryological material at the Puget Sound Biological Station. Publ. Puget Sound Biol. Stn. Univ. Wash. 2: 127-137.

CARLgRen, O. 1934. Some Actinaria from Bering Sea and arctic waters. J. Wash. Acad. Sci. 24: 348-353.

1949. A survey of the Ptychodactiaria, Corallimorpharia and Actiniaria. K. Sven. Vetenskapsakad. Handl. Ser. 4, 1(1): 1-121.

DunN, D. F. 1975 a. Gynodioecy in an animal. Nature (London), 253: $528-529$.

-1975b. Reproduction of the externally brooding sea anemone Epiactis prolifera Verrill, 1869. Biol. Bull. (Woods Hole, Mass.), 148: 199-218.

1977. Variability of Epiactis prolifera (Coelenterata: Actiniaria) in the intertidal zone near Bodega Bay, California. J. Nat. Hist. 11: 457-463.
1983. Some Antarctic and Sub-Antarctic sea anemones (Coelenterata: Ptychodactiaria and Actiniaria). Antarct. Res. Ser. 39(1): 1-67.

DunN, D. F., F.-S. ChIA, and R. Levine. 1980. Nomenclature of Aulactinia (=Bunodactis), with description of Aulactinia incubans n.sp. (Coelenterata: Actiniaria), an internally brooding sea anemone from Puget Sound. Can. J. Zool. 58: 2071-2080.

FisCHER, P. 1889. Nouvelle contribution à l'actinologie française. Première partie. Actes Soc. Linn. Bordeaux, 43: 252-309.

Francrs, L. 1973. Intraspecific aggression and its effect on the distribution of Anthopleura elegantissima and some related sea anemones. Biol. Bull. (Woods Hole, Mass.), 144: 73-92.

GHISELIN, M. T. 1969. The evolution of hermaphroditism among animals. Q. Rev. Biol. 44: 189-208.

HAND, C. 1955. The sea anemones of central California. Part II. The endomyarian and mesomyarian anemones. Wasmann J. Biol. 13: 37-99.

HAND, C., and D. F. DUNN. 1974. Redescription and range extension of the sea anemone Cnidopus ritteri (Torrey) (Coelenterata: Actiniaria). Wasmann J. Biol. 32: 187-194.

LENHOFF, H. M. 1965. Mechanical stimulation of feeding in Epiactis prolifera. Nature (London), 207: 1003.

PURCELL, J. 1977. Aggressive function and induced development of catch tentacles in the sea anemone Metridium senile (Coelenterata, Actiniaria). Biol. Bull. (Woods Hole, Mass.), 153: 355-368.

RIFKIN, J., and R. ENDEAN. 1983. The structure and function of the nematocysts of Chironex fleckeri Southcott, 1956. Cell Tissue Res. 233: 563-577.

Siebert, A. E., and J. G. Spaulding. 1976. The taxonomy, development and brooding behavior of the anemone, Cribrinopsis fernaldi sp. nov. Biol. Bull. (Woods Hole, Mass.), 150: 128-138.

TORREY, H. B. 1902. Papers from the Harriman Alaska Expedition. XXX. Anemones, with discussion of variation in Metridium. Proc. Wash. Acad. Sci. 4: 373-410.

UCHIDA, T. 1934. A brood-caring actinian subject to a wide range of colour variation. J. Fac. Sci. Hokkaido Univ. Ser. 6, Zool. 3: 17-31.

VERRILL, A. E. 1869. Review of the corals and polyps of the west coast of America. Trans. Conn. Acad. Arts Sci. 1: 377-567.

Watson, G. M., and R. N. Mariscal. 1983. The development of a sea anemone tentacle specialized for aggression: morphogenesis and regression of the catch tentacle of Haliplanella luciae (Cnidaria, Anthozoa). Biol. Bull. (Woods Hole, Mass.), 164: 506-517. 